\title{
PENGARUH KEPERCAYAAN SISWA PADA MATEMATIKATERHADAP KEMAMPUAN BERPIKIR KRITIS DAN HASIL BELAJAR SISWA
}

\author{
AMINULLAH \\ Program Studi Teknik Sipil Kampus Mataram UNMAS Denpasar \\ e-mail :aminullahmtk@gmail.com
}

\begin{abstract}
ABSTRAK
Penelitian ini bertujuan untuk mendeskripsikan pengaruh kepercayaan siswa pada matematika terhadap kemampuan berpikir kritis dan hasil belajar siswa. Penelitian ini merupakan penelitian eksperimen semu, sampel dalam penelitian ini yaitu siswa kelas $X$ jurusan akomodasi perhotelan sejumlah 30 siswa.Pengambilan data menggunakan instrumen angket dan tes. Hasil penelitian ini menunjukkan bahwarata-rata kepercayaan siswa pada matematika sebesar 58,06 dengan standar deviasi sebesar 3,65. Sedangkan kemampuan berpikir kritis dan hasil belajar siswa diperoleh rata-rata 56,94 dengan standar deviasi 9,63. Pengaruh kepercayaan siswa pada matematika terhadap kemampuan berpikir kritis dan hasil belajar siswamemiliki pengaruh yang posistif ditunjukkan dengan $\mathrm{F}$ hitung $(4,485) \geq \mathrm{F}$ tabel $(4,18)$ atau angka signifikansi pada ANOVA0,043 $\leq 0.05$. Besarnya pengaruh kepercayaan siswa pada matematika terhadap kemampuan berpikir kritis dan hasil belajar siswa sebesar 13,4\%. Persamaan regresi yang diperoleh $\widehat{\boldsymbol{Y}}=0,866+0,966 \boldsymbol{X}+\epsilon$. Artinya jika nilai kepercayaan siswa pada matematika sebesar 1 satuan, maka nilai variabel prediksi akan bertambah sebesar 0,966. Semakin tinggi kepercayaan siswa pada matematika, maka kemampuan berpikir kritis dan hasil belajar siswa juga akan semakin meningkat.
\end{abstract}

Kata kunci: kepercayaan pada matematika, kemampuan berpikir kritis.

\section{ABSTRACT}

This study aims to describe the effect of student confidence in mathematics on critical thinking skills and student learning outcomes. This research is a quasi-experimental study, the sample in this study is $X$ class students majoring in hotel accommodation as many as 30 students. Retrieval of data using questionnaire and test instruments. The results of this study indicate that the average student confidence in mathematics is 58.06 with a standard deviation of 3.65. While the ability to think critically and student learning outcomes obtained an average of 56.94 with a standard deviation of 9.63. The influence of students' trust in mathematics on critical thinking skills and student learning outcomes have a positive effect shown by $F$ arithmetic $(4,485) \geq F$ table (4.18) or the significance number in ANOVA $0.043 \leq 0.05$. The magnitude of the effect of students' trust in mathematics on critical thinking skills and student learning outcomes of $13.4 \%$. The regression equation obtained by $Y^{\wedge}=0.866+0.966 X+\epsilon$. This means that if the value of students' trust in mathematics is 1 unit, the value of the predicted variable will increase by 0.966 . The higher the student's confidence in mathematics, the ability to think critically and student learning outcomes will also increase.

Keywords: trust in mathematics, critical thinking skills

\section{PENDAHULUAN}

\section{Latar Belakang}

Keberhasilan proses belajar mengajar di kelas dipengaruhi oleh faktor internal dan eksternal, baik dari pribadi siswa, guru, lingkungan belajar dan bahkan minat terhadap mata pelajaran dipelajarai.Salah satu mata pelajaran yang jarang diminati oleh siswa terutama siswa SMK yang jurusannya pariwisata atau bukan sains.Kepercayaan siswa yang berpikir bahwa matematika itu tidak dipakai dalam penerapan bidang ilmu yang digeluti lebih rendah dengan dari siswa yang merasa bahwa matematika itu penting atau dibutuhkan.Kepercayan siswa pada matematika adalah persepsi pribadi yang dimiliki oleh siswa baik secara 
implisit maupun eksplisit.Persepsi tersebut tentang pendidikan matematika, tentang dirinya sendiri sebagai matematikawan, dan tentang konteks matematika dalamkelas (Eynde, De Corte, dan Verchaffel, 2002).Menurut Mutodi dan Ngirande, (2014) bahwa mitos dan kepercayaan tentang matematika siswa sangat berpengaruh pada kesukaan atau ketidaksukaan siswa terhadap matematika.Jadi dapat dikatakan bahwa kepercayaan siswa terhadap matematika tergantung pandangan pribadi atau persepsi terhadap matematika itu sendri baik dari segi kebutuhan ataupun kebermanfaatan di masa depan.

Manfaat mempelajari suatu mata pelajaran bukan hanya terfokus pada pemahaman pada mata pelajaran itu sendiri tetapi diharapkan dapat berdampak pada kemampuan lain yang dapat menunjang bidang ilmu atau ketrampilan yang dimiliki oleh siswa. Sesuai pendapat Goldin, Rosken dan Torner (2009) bahwabelief matter, kepercayaan memberikan perbedaan pengaruh pada setiap orang yang terlibat dalam matematika. Kepercayaan terhadap matematika diharapkan mampu meningkatkan kemampuan matematis sehingga terwujud tujuan pemebelajaran itu sendiri yaitu sesuai yang tertulis dalam Permen nomor 64 tahun 2013 tentang standar isi menyatakan bahwa siswa diharapkan untuk logis, kritis, analitis, cermat dan teliti, bertanggung jawab, responsif, dan tidak mudah menyerah dalam menyelesaikan persoalan.

Salah satu tujuan pembelajaran yaitu pembentukan atau peningkatan cara berpikir siswa diantaranya berpikir kritis. Siswayang memiliki kemampuan berpikir kritis tidak hanya akan menerima informasi tetapi juga mampu menggunakan informasi tersebut (Snyder dan Snyder, 2008). Peran lain berpikir kritis pada seseorang adalah dengan memiliki kemampuan ini, seseorang akan memiliki pemikiran yang berasalan, pemikiran reflekif, pemikiran yang fokus, mengamabil keputusan apa yang harus dipercaya atau dilakukan, dan kemampuan disposisi (Nitko dan Brookhart, 2011). Sedangkan menurut Samanci (2015) menyatakan bahwa kemampuan berpikir kritis mempengaruhi prestasi belajar dan cukup mempengaruhi kemampuan penilaian moral.Namun sulitanya mengukur kemampuan berpikir kritis itu membuat guru jarang menilai atau memperhatikan kemampuan tersebut, sesuai menurut Kerkman dan Johnson (2014) bahwa secara umum, salah satu tujuan dari pendidikan yang lebih baik adalah diperolehnya kemampuan berpikir kritis, akan tetapi masih jarang persetujuan antara apa itu kemampuan berpikir kritis, atau apa bukti dari berpikir kritis itu sendiri.

Kemampuan berpikir kritis siswa akan terbentuk dari keseriusan dan keingintahuan siswa pada suatu permasalahan matematika, sehingga keseriusan atau keingintahuan itu akan muncul dari kepercayaan terhadap matematika bahwa yang dilakukan itu berguna atau bermanfaat.Kemampuan berpikir kritis siswa juga merupakan tujuan atau hasil belajar sesuai Permen nomor 64 tahun 2013. Sehingga akan dilihat pengaruh kepercayaan siswa pada matematika terhadap kemampuan berpikir kritis siswa.

\section{Rumusan Masalah}

Berdasarkan latar belakang, maka rumusan masalah dalam penelitian ini yaitu"apakah ada pengaruh kepercayaan siswa pada matematika terhadap kemampuan berpikir kritis dan hasil belajar siswa ?".

\section{Tujuan Penelitian}

Tujuan penelitian ini adalah untuk mendeskripsikan pengaruh kepercayaan siswa pada matematika terhadap kemampuan berpikir kritis dan hasil belajar siswa.

\section{METODOLOGI PENELITIAN}

Penelitian ini merupakan kuasi eksperimen atau penelitian eksperimen semu dan sampel dalam penelitian ini yaitu siswa kelas $X$ jurusan akomodasi perhotelan SMKN 4 Mataram sejumlah 30 siswa. Penelitian ini dilaksankan bulan Mei 2019 dengan pengambilan data menggunakan instrumen angket dan tes.Angket digunakan untuk mendapatkan data mengenai kepercayaan siswa terhadap matematika dan tes digunakan untuk memperoleh data mengenai kemampuan berpikir kritis siswa dan hasil belajar siswa.Tes hasil belajar dijadikan satu dengan tes kemampuan berpikir kritis siswa, artinya hasil belajar ditunjukkan juga oleh kemampuan berpikir kritis siswa.Analisis data dalam penelitian ini menggunakan analisis regresi linear sederhana dengan persamaan $\widehat{\mathrm{Y}}=\mathrm{a}+\mathrm{bX}+\epsilon$.Adapun hipotesis yang diuji dalam penelitian inisebagai berikut :

Ho : Tidak ada pengaruh kepercayaan siswa pada matematika $(X)$ terhadap kemampuan berpikir kritis dan hasil belajar siswa $(Y)$.

Ha: Ada pengaruh kepercayaan siswa pada matematika $(X)$ terhadap kemampuan berpikir kritis dan hasil belajar siswa $(Y)$. 
Pengujian untuk menunjukkan kebenaran hipotesis diatas dibuktikan dari pengaruh variabel $\mathrm{X}$ pada variabel Y dmenggunakan analisis regresi, dengan ketentuan sebagai berikut:

Ho ditolak/ Ha diterima : Jika F hitung $\geq F$ tabel atau angka signifikansi pada ANOVA sebesar $\leq 0.05$

Ho diterima/ Ha ditolak : Jika F hitung < Ftabel atau angka signifikansi pada ANOVA sebesar > 0.05 16.0 .

Pengolahan, analisis serta pengujian data dalam penelitian ini menggunakan bantuan software SPSS

\section{HASIL DAN PEMBAHASAN}

Hasil penelitian ini terfokus pada uji hipotesis yang akan menunjukkan atau mendeskripsikan pengaruh kepercayaan siswa pada matematika terhadap kemampuan berpikir kritis dan hasil belajar siswa. Pengukuran hasil belajar dalam penelitian ini tidak dilakukan secara spesifik karena kemampuan berpikir kritis juga merupakan hasil belajar siswa. Berdasarkan data yang diperoleh oleh peneliti dari 30 siswa menunjukkan bahwa rata-rata tingkat kepercayaan siswa terhadap matematika sebesar 58,06 dengan standar deviasi sebesar 3,65. Sedangkan rata-rata kemampuan berpikir kritis siswa berdasarkan 5 soal esai yang sudah dijawab siswa sebesar 56,94 dengan standar deviasi sebesar 9,63. Rata kepercayaan siswa pada matematika dan kemampuan berpikir kritis siswa sangat perlu ditingkatkan karena masih tergolong rendah.

Ananlisis data untuk menunjukkan pengaruh kepercayaan siswa pada matematika terhadap kemampuan berpikir kritis siswa menggunakan analisis regresi linear berbantu program computer SPSS.16.0 dengan hasil deskripsi diterangkan melalui hasil atau output program tersebut.Analisis regresi dilakukan setelah melalui uji asumsi klasik.Adapun hasil analisis regresi atau hasil dalam penelitian ini dideskripsikan sebagai berikut.

Tabel 1. ANOVA ${ }^{b}$

\begin{tabular}{|ll|r|r|r|r|r|}
\hline Model & & Sum of Squares & df & Mean Square & F & \multicolumn{1}{c|}{ Sig. } \\
\hline 1 & Regression & 372.859 & 1 & 372.859 & 4.485 & $.043^{\mathrm{a}}$ \\
& Residual & 2411.012 & 29 & 83.138 & & \\
& Total & 2783.871 & 30 & & & \\
\hline
\end{tabular}

a. Predictors: (Constant), Kepercayaan

b. Dependent Variable: Berpikir_Kritis

Berdasarkan hipotesis yang sudah diajukan sebelumnya, bahwa jika $\mathrm{F}$ hitung $\geq \mathrm{F}$ tabel atau angka signifikansi pada ANOVA sebesar $\leq 0.05$ maka Ho ditolak/ Ha diterima. Sedangkan jika F hitung < Ftabel atau angka signifikansi pada ANOVA sebesar > 0.05 maka Ho diterima/ Ha ditolak. Tabel ANOVA menunjukkan bahwa $\mathrm{F}$ hitung $(4,485) \geq \mathrm{F}$ tabel $(4,18)$ atau angka signifikansi pada ANOVA0,043 $\leq 0.05$, sehingga Ha diterima/ Ho ditolak. Artinya bahwa Ada pengaruh kepercayaan siswa pada matematika $(X)$ terhadap kemampuan berpikir kritis dan hasil belajarsiswa (Y).Sedangkan untuk mengetahui besarnya pengaruh kepercayaan pada matematika terhadap kemampuan berpikir kritis dan hasil belajar siswa dapat dilihat dari tabel berikur.

Tabel 2. Model Summary ${ }^{b}$

\begin{tabular}{|l|r|r|r|r|r|}
\hline Model & \multicolumn{1}{|c|}{$\mathrm{R}$} & R Square & \multicolumn{1}{c|}{$\begin{array}{c}\text { Adjusted R } \\
\text { Square }\end{array}$} & $\begin{array}{l}\text { Std. Error of the } \\
\text { Estimate }\end{array}$ & Durbin-Watson \\
\hline 1 & $.366^{\mathrm{a}}$ & .134 & .104 & 9.11802 & 1.811 \\
\hline
\end{tabular}

a. Predictors: (Constant), Kepercayaan

b. Dependent Variable: Berpikir_Kritis

$R$ Square pada tabel 2 sebesar 0,134 yang menunjukkan besarnya pengaruh $X$ terhadap $Y$. Besarnya pengaruh kepercayaan siswa pada matematika terhadap kemampuan berpikir kritis dan hasil belajar siswa sebesar 13,4\% dan 86,6\% lainnya dipengaruhi oleh factor lain. 13,4\% termasuk angka yang kecil, namun angka tersebut menunjukkan bahwa ada pengaruh kepercayaan siswa pada matematika terhadap kemampuan berpikir kritis siswa. Sedangkan persamaan atau model regresi dari hasil penelitian ini dapat diketahui melalui tabel 3 berikut. 
Tabel 3. Coefficients ${ }^{\mathrm{a}}$

\begin{tabular}{|c|c|c|c|c|c|c|}
\hline \multirow{2}{*}{\multicolumn{2}{|c|}{ Model }} & \multicolumn{2}{|c|}{ Unstandardized Coefficients } & $\begin{array}{l}\text { Standardized } \\
\text { Coefficients }\end{array}$ & \multirow[b]{2}{*}{$\mathrm{t}$} & \multirow[b]{2}{*}{ Sig. } \\
\hline & & B & Std. Error & Beta & & \\
\hline \multirow[t]{2}{*}{1} & (Constant) & .866 & 26.527 & & .033 & .974 \\
\hline & Kepercayaan & .966 & .456 & .366 & 2.118 & .043 \\
\hline
\end{tabular}

a. Dependent Variable: Berpikir_Kritis

Unstandardized Coefficientspada kolom B dalam tabel 3 tersebut menunjukkankonstanta dan koefesien model persamaan regresi yang terbentuk, sehingga persamaan regresi yang terbentuk diperoleh:

$$
\widehat{\boldsymbol{Y}}=0,866+0,966 \boldsymbol{X}+\epsilon .
$$

Perhatikan bahwa konstanta regresi pada persamaan di atas menunjukkan nilai sebesar 0,866.Sedangkan koefisien $X$ menunjukkan pengaruh nilai $X$ (kepercayaan pada matematika) terhadap Yprediksi (kemampuan berpikir kritis dan hasil belajar). Artinya jika nilai kepercayaan siswa pada matematika sebesar 1 satuan, maka nilai variabel prediksi akan bertambah sebesar 0,866 . Hal ini berarti kepercayaan siswa pada matematika memiliki pengaruh yang positif terhadap kemampuan berpikir kritis dan hasil belajar siswa.Jadi dapat dikatakan, jika kepercayaan siswa pada matematika meningkat, maka kemampuan berpikir kritis dan hasil belajar siswa juga akan semakin meningkat.Hasil penelitian ini sesuai dengan pendapat Gómez-Chacón dkk (2011) yang mengungkapkan bahwa nilai dari tes kognitif, kepercayaan pada matematika, dan kepercayaan pada kompetensi sendiri dapat menjadi prediksi dari kinerja matematika.Sejalan juga dengan pendapat Malmivuori (1994) yang menyatakan bahwa tidak hanya guru yang berpengaruh pada hasil pembelajaran, tetapi juga sistem kepercayaan siswa yang didalamnya terdapat kepercayaan terhadapmatematika.

Hasil penelitian ini sesuai dengan hasil penelitian yang sudah dilakukan olehSuthar V, dkk (2010)yang berjudul 'Students' Beliefs on Mathematics and Achievement of UniversityStudents: Logistics Regression Analysis" dilakukan pada mahasiswa S1 dari tigainstitusi matematika di tiga universitas berbeda daerah Klang Valley tahun ajaran2009-2010. Hasil penelitiannya menunjukkan bahwa perbedaan tingkat kepercayaan pada matematika dari mahasiswa yang memilikinilai rendah dan tinggi.Mahasiswa yang memiliki nilai tinggi memilikikepercayaan pada matematika lebih tinggi dibandingkan dengan mahasiswa yangmemiliki nilai rendah.

\section{SIMPULAN DAN SARAN}

\section{Simpulan}

Kepercayaan siswa pada matematika memiliki pengaruh yang posistif terhadap kemampuan berpikir kritis dan hasil belajar siswa. Tingkat kepercayaan siswa dengan rata-rata sebesar 58,06 dan rata-rata kemampuan berpikir kritis dan hasil belajar siswa sebesar 56, 94. Sedangkan bukti berpengaruhnya kepercayaan pada matematika terhadap kemampuan berpikir kritis dan hasil belajar ditunjukkan oleh F hitung $(4,485) \geq$ F tabel $(4,18)$ atau angka signifikansi pada ANOVA0,043 $\leq 0.05$ dan tingkat pengaruhnya sebesar $13,4 \%$. Adapun persamaan regresi yang diperoleh $\widehat{\boldsymbol{Y}}=0,866+0,966 \boldsymbol{X}+\epsilon$. Artinya jika nilai kepercayaan siswa pada matematika sebesar 1 satuan, maka nilai variabel prediksi akan bertambah sebesar 0,966. Semakin tinggi kepercayaan siswa pada matematika, maka kemampuan berpikir kritis dan hasil belajar siswa juga akan semakin meningkat.

\section{Saran}

Berdasarkan hasil penelitian ini, maka saran yang dapat disampaikan sebagai berikut:

1. Kepercayaan siswa pada matematika itu penting dalam memahami matematika, sehingga perlu diukur dan ditingkatkan oleh guru atau ppendidik.

2. Guru atau pendidik perlu melakukan penelitian-penelitian terkait kegiatan pembelajaran untuk mencapai tujuan pembelajaran yang sudah ditetapkan 
3. Kemampuan berpikir kritiis dan hasil belajar siswa dapat ditingkatkan melalui peningkatan kepercayaan siswa terhadap matematika.

\section{DAFTAR PUSTAKA}

Eynde, P., De Corte, E., \& Verschaffel, L. (2002).Framing student's mathematics-related beliefs: a quest for conceptual clarity and a comprehensive categorization.Dalam Leder, G.C., Pehkonen, W., \&Torner, G. (Eds.), Beliefs; A Hidden Variable in Mathematics Education?(pp.13-37). London: Kluwer Academics Publisher.

Goldin, G., Rösken, B., \& Törner, G. (2009). Beliefs - no longer a hidden variable in mathematical teaching and learning processes. Dalam Jürgen Maßß \& Wolfgang Schlöglmann (Eds), Beliefs and Attitudes in Mathematics Education (pp.1-18). Rotterdam, The Netherlands: Sense Publishers.

Gómez-Chacón, I. M., García-Madruga, J. A., Rodríguez, R., Vila, J. Ó., \& Elosúa, M. R. (2011). Mathematical beliefs and cognitive reflection: Do they predict academic chievement?. Proceedings of the MAVI-17 Conference, Ruhr-Universität Bochum, Germany, 64-73.

Kerkman, Dennis D. \& Johnson, Andrew T. (2014). Challenging multiple-choicequestions to engage critical thinking. InSight: A Journal of ScholarlyTeaching, 9, 92-97.

Malmivuori, Marja-Liisa. (1994). Study on affective factors in mathematics learning. Proceedings of the Nordic Conference on Mathematics Teaching (NORMA-94), Lahti, 127-131.

Mutodi, Paul \& Ngirande, Hlanganipai. (2014). The influence of students perceptions on mathematics performance: A case of a selected high school in South Africa. Mediterranean Journal of Social Sciences, 5(3), 431-445.

Nitko, A. J. \& Brookhart, S. M. (2011). Educational assesment of students $6^{\text {th }}$ edition. USA: Pearson Education, Inc.

Samanci, Nilay Keskin. (2015). A study on the link between moral judgmentcompetences and critical thinking skills. International Journal ofEnvironmental \& Science Education, 10(2), 135-143. Doi:10.12973/ijese.2015.236a.

Snyder L. G. \& Snyder, M. J. (2008).Teaching critical thinking and problem solving skills. The Delta Pi Epsilon Journal, 50(2), 90-99.

Suthar, V., Tarmizi, R. A., Midi, H., \& Adam, M. B. (2010). Students' beliefs onmathematics and achievement of university students: Logistics regressionanalysis. Procedia Social and Behavioral Sciences, 8, 525-531. 